flow of ideas and even people between themselves. Orlov and company have plenty to complain about.

There have been several well-publicized international shouting matches, most recently at Madrid, but the agreements have also led to the Stockholm talks on European security, now under way, which may yet make ten years of diplomacy seem worthwhile. In any case, Orlov was not imprisoned for having discovered that the Helsinki agreements were being illiberally interpreted (more simply, ignored) by Soviet authorities, but for having said so, and for having distributed his complaints abroad.

By that test, Orlov is unquestionably a criminal. Did not a Soviet court, whose judicial independence is guaranteed by the Soviet constitution, come to that conclusion? Is it not, in any case, well known that the Soviet authorities, like their tsarist predecessors, have always taken a serious view of what seems to be disloyalty? With the obligations of individuals to the state counting for more than the state's obligation towards its people as individuals, Orlov must have known that he was asking for trouble. Orlov's activities had much in common with those of earlier trouble-makers. Medvedev, Solzhenitsyn and the like find some weakness in the system, such as the constitutional right that private correspondence should not be interfered with, exploit it to the full and, provided they keep within the law, sooner or later find themselves at an airport with an exit visa in their pocket. Orlov must have overstepped the line.

This is how Orlov's case seems to many honest Soviet citizens. People elsewhere distressed at Orlov's plight must take that disconcerting circumstance into their calculations. Two conclusions follow. First, on compassionate grounds, anything that will help to release Orlov from the plight in which he finds himself is to be welcomed. If the petition signed by 2,600 French physicists, or the proposal being canvassed among the accelerator people at Geneva that Orlov should be offered a job at the European Organization for Nuclear Research (CERN), will help towards that end, all well and good. But the chances are not high. That is why this sad occasion should be a reminder to complainants in the West that their quarrel with the Soviet authorities goes deeper than the circumstances of Orlov's imprisonment and is tantamount to a protest against Soviet law and the manner in which it is interpreted. But sovereign governments do not often change their legislation at the behest of people who live elsewhere. So, for the long haul, the complainants must find subtle ways of making their opinions felt. The proposal, put forward last week, that there should be an Orlov Prize to honour people like him, will not help and may even hinder. Breaking off such personal scientific collaborations with Soviet scientists as have survived the past few years would be similarly nugatory. It will be better to keep the links going and to use them as a means of convincing collaborators that there are good reasons why the law needs changing. Orlov's objective, after all, is that his own brave act should ensure that there is less need of an army of successors.

\section{What hope for Esprit?}

\section{The European plan for information technology research is likely to be launched too late.}

THE European Communities are more conspicuously than usual travelling in cloud-cuckoo land. Last week, the Commission, the Communities' executive authority, put the finishing touches to its plan for supporting long-term research in information technology by means of an intricate system of research contracts to be let by Brussels to companies and other research organizations which are themselves willing to meet half the cost.

The European strategic programme of research and development in information technology (known as Esprit) has recently been nurtured by Etienne Davignon, the Commissioner for Industry in Brussels, who has been shuttling about Europe seeking promises of support. On Monday, Davignon spent 50 minutes at 10 Downing Street with the British Prime Minister; the hope now is that if British objections can be overcome, the project will be approved at a meeting of ministers on 28 February, whereupon the Commission will be free to spend roughly US $\$ 400$ million sterling of its own money provided that its partners commit an equal sum over the succeeding five years. The drawback, for the time being set aside in Brussels, is that the Commission is certain on present form to run out of funds between June and September. In short, the Commission has no money for projects like Esprit, and will not know whether it will be in funds again until the meeting of the heads of European governments fixed for 20 and 21 March. On recent form, the chances that the Communities' deep-seated differences can be resolved at a single meeting, and before the last minute has arrived (which will not be until June), are negligible.

So will Esprit be another European dream impaled on the failure of European governments to agree what should be done with their common enterprise? If it is, it will not be the first casualty of this kind. In the 1950s, Euratom, then legally a community in its own right, embarked on an ambitious programme for the development of nuclear reactors whose hallmark was that their design had nothing in common with those of the reactors being developed in member states. Member governments would not countenance the threat of competition between their own national nuclear energy establishments and the common enterprise, but the result was what everybody would have been entitled to predict: Euratom's projects failed (as did many of those mounted nationally). The idea that there might be a European project to strengthen the technology of the computer and communications industry was the most prominent of the proposals canvassed in the late 1960 s by M. Pierre Aigrain, then President Pompidou's chief scientist. That came to grief for two reasons - the resistance of European telecommunications monopolies to the suggestion that their own research was insufficient and the lack of a plan to suggest how a common research programme supported by established companies or nationalized industries could nevertheless yield benefits that would be widely shared. Aigrain's project came too soon.

The Commission's latest attempt to breathe life into European information technology has obviously been designed to avoid these pitfalls, but has weaknesses of its own. Participation in the programme will be voluntary, but collaborating companies or consortia will have to commit resources to projects that the Commission supports. This will ensure a degree of seriousness. There are also rules about the availability of the results of research and development projects although, inevitably and even equitably, the partners in the research projects will have an advantage over others in their exploitation deriving from familiarity with the work. Perhaps the most encouraging feature of the Esprit programme is that it seems already to have fostered a degree of collaboration between European companies hitherto not much used to talking to each other. But the question remains of whether Esprit is what Europe most needs.

That information technology offers great opportunities for European industry, and that technology of the kind now being applied is likely to seem, a few decades from now, a rudimentary tool, are nowhere denied. Most industrial organizations recognize which way the wind is blowing. But the impediments to faster development consist not so much of the lack of development projects as of the shortage of people able to turn bright ideas into working machines decisively and quickly, the lack of technical people able to service the machines actually sold to customers (which demands more skill than that required to order a package of software from a list) and too little support for really long-term projects, those that might lead to optical computers for example (see Nature 9 February, p.494). For all the delicacy with which Esprit has been conceived, the programme will help towards these ends only incidentally, by training people. Might not the same result have been obtained by other means? (The same criticism can be made of the British Government's Alvey programme.) The risk in what the Commission is proposing is that a great deal of money (which does not exist) may be spent ineffectually. The danger is that if the Commission fails with this huge project, it may not be given another chance. 